\title{
Palynology of the Dinosaur Beds of Tendaguru (Tanzania) - Preliminary Results
}

\section{Eckart Schrank ${ }^{1}$}

With 2 figures, 3 plates and 2 tables

\begin{abstract}
The Tendaguru Beds, southeastern Tanzania, have yielded two palynological assemblages of Kimmeridgian to Tithonian age: (1) the Anapiculatisporites-Densoisporites-Trisaccites assemblage from the Middle Saurian Beds and (2) the Barbatacysta-Pareodinia assemblage from the overlying Smeei Beds. A third assemblage with Rhizophagites and rare angiosperm pollen from the Upper Saurian Beds is contaminated by recent and subrecent material.

The Anapiculatisporites-Densoisporites-Trisaccites assemblage is characterized by the presence of freshwater algae (Ovoidites), pteridopyhtic-bryophytic spores and gymnosperm (conifer) pollen, with Classopollis as the most abundant element. Among the rare elements of this assemblage is the questionable dinoflagellate Mendicodinium ? quadratum, possibly a Kimmeridgian-Tithonian marker. The miospores show palaeobiogeographic links to Southern Gondwana, especially Madagascar, Australia, Argentina and India. Deposition of this assemblage took place in an aquatic environment with strong palynological influx from a terrestrial source and questionable marine influence.

The Barbatacysta-Pareodinia assemblage contains a considerable number of dinoflagellates suggesting deposition in a marine environment. The terrestrially-derived miospores are impoverished and dominated by conifer pollen, while pteridophyticbryophytic spores form a very subordinate element or are absent.
\end{abstract}

Key words: Dinoflagellates, pollen, spores, Late Jurassic, Tanzania.

\section{Zusammenfassung}

Die Tendaguru-Schichten, Südost-Tansania, haben zwei palynologische Assoziationen, deren Alter als Kimmeridge bis Tithon interpretiert wird, geliefert. Die Anapiculatisporites-Densoisporites-Trisaccites-Assoziation stammt aus den Mittleren Saurierschichten, und die Barbatacysta-Pareodinia-Assoziation charakterisiert die darüberlagernden Smeei-Schichten. Eine dritte Vergesellschaftung mit Rhizophagites und seltenen Angiospermen-Pollen aus den Oberen Saurierschichten ist durch rezentes bis subrezentes Material kontaminiert.

Die Anapiculatisporites-Densoisporites-Trisaccites-Assoziation ist durch die Anwesenheit von Süßwasser-Algen (Ovoidites), Pteridophyten-Bryophyten-Sporen und Gymnospermen-Pollen (Koniferen) gekennzeichnet mit Classopollis als dem häufigsten Element. Zu den seltenen Elementen dieser Assoziation gehört der fragliche Dinoflagellat Mendicodinium ? quadratum, der möglicherweise als leitend für das Kimmeridge-Tithon angesehen werden kann. Die Miosporen zeigen paläobiogeographische Verbindungen nach Südgondwana, besonders nach Madagaskar, Australien, Argentinien und Indien. Das Ablagerungsmilieu dieser Assoziation war aquatisch mit starker Zufuhr von terrigenem Material, während mariner Einfluß fraglich ist.

Die Dinoflagellaten-führende Barbatacysta-Pareodinia-Assoziation wurde in einem marinen Milieu gebildet, in dem die Zufuhr terrigener Palynomorphe reduziert und im wesentlichen auf Koniferen-Pollen beschränkt war, während PteridophytenBryophyten-Sporen nur sehr untergeordnet vorkommen oder ganz fehlen.

Schliisselwörter: Dinoflagellaten, Pollen, Sporen, Oberjura, Tansania.

\section{Introduction}

The area around Tendaguru, a hill in southeastern Tanzania (Fig. 1), is known to harbour one of the most important dinosaur deposits of Africa. Descriptions of the regional geology and stratigraphy of this area have been given by Aitken (1961), Kent et al. (1971) and Zils et al. (1995).
These sources also provide information on the extensive history of research including the German Tendaguru Expedition (1909-1913) which Russell et al. (1980) praise as "one of the greatest multidisciplinary paleontological expeditions of all time".

Despite the fact that the Tendaguru Beds have also yielded rich marine invertebrate faunas

\footnotetext{
${ }^{1}$ Institut für Angewandte Geowissenschaften II, Technische Universität Berlin, Sekr. EB 10, Ernst-Reuter-Platz 1, D-10587 Berlin, Germany.

E mail: E.Schrank@TU-Berlin.DE

Received January 1999, accepted April 1999
} 


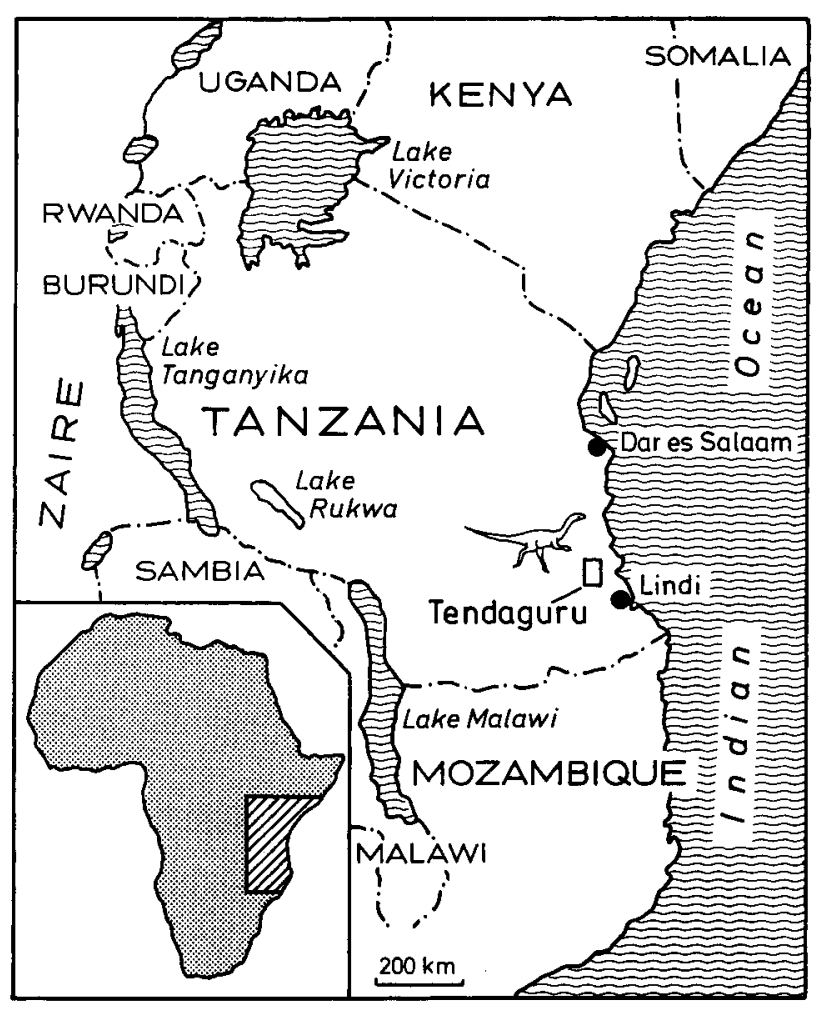

Fig. 1. Sketch map of Eastern Africa showing the approximate position of the Tendaguru dinosaur locality

(e.g. Janensch 1914, Zwierzycki 1914, see also Fig. 2), there are still problems related to the biostratigraphy and depositional history of the dinosaur beds. In the classical reports of the German Tendaguru Expedition, the various micropalaeontological disciplines are for obvious reasons absent. Among these palynology is nowadays a standard tool used in the interpretation of intercalating marine and nonmarine sedimentary successions as present in the Tendaguru Beds. Earlier attempts of a few palynologists to study Tendaguru sediments on the basis of a low number of samples remained largely inconclusive (Herngreen, personal communication) or re-
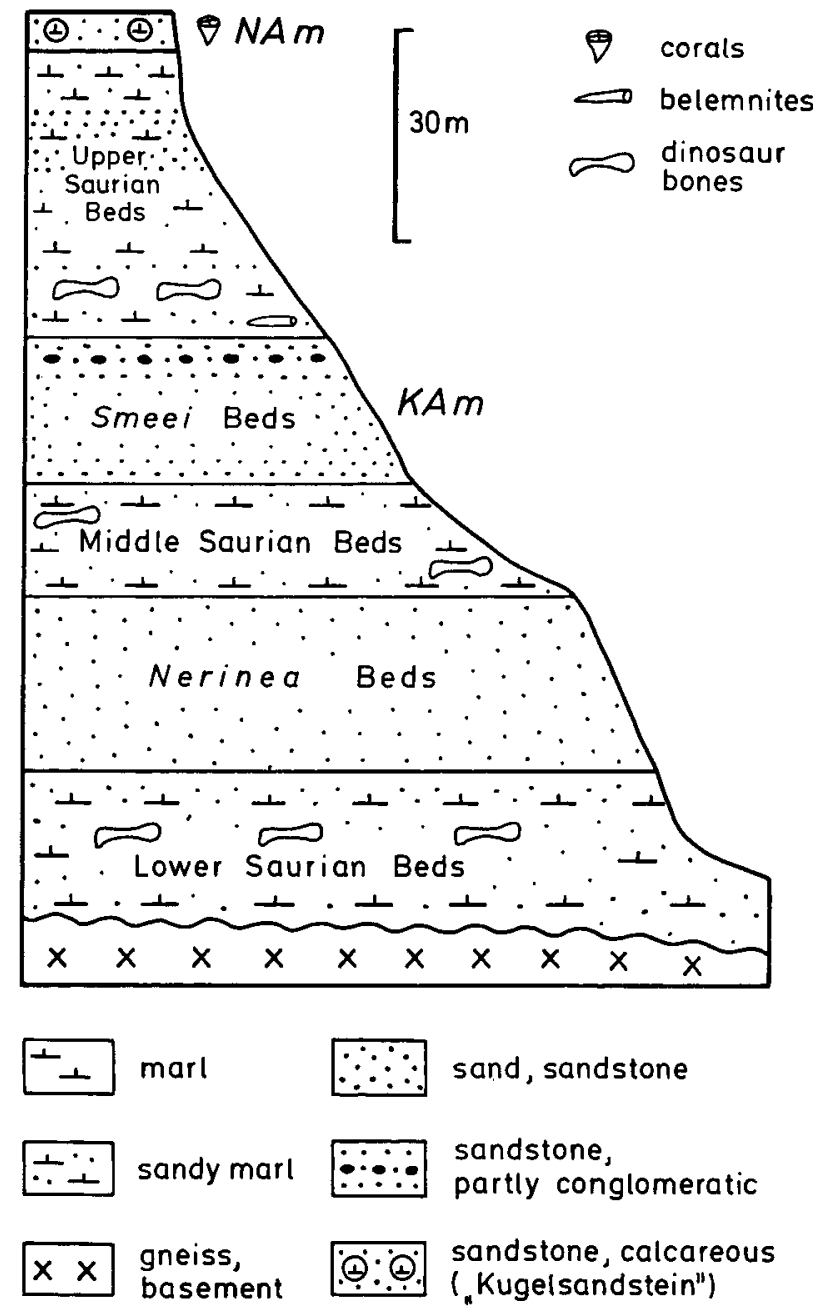

Fig. 2. Generalized section of the Tendaguru dinosaur beds compiled from the descriptions of Janensch (1914). Abbreviations: NAm, Neocomian ammonites; KAm, late Kimmeridgian to Tithonian ammonites according to Zwierzycki (1914)

sulted in the recovery of few palynomorph types from a single sample (Jarzen 1981).

For the present study more than 100 samples from the Tendaguru collections of the Museum für Naturkunde (Berlin) were investigated. Among them about 9 samples (Table 1) are pro-

Table 1

Palynologically productive samples from the Tendaguru Beds used in the present study.

\begin{tabular}{|c|c|c|}
\hline $\begin{array}{l}\text { TU Berlin } \\
\text { slide numbers }\end{array}$ & Stratigraphic level & Text from original label \\
\hline AKA & Middle Saurian Beds & $\begin{array}{l}\text { Grünliche Cyrena-Mytilus-Sandmergel der mittleren Saurierschicht, } \\
\text { Tingutiguti-Bach unterhalb der Quelle }\end{array}$ \\
\hline ALB & & Cyrenen-Mergel der mittleren Saurierschicht \\
\hline AMB & & Cyrena-Mergel der mittleren Saurierschicht, Kitukituki-Bach \\
\hline AMC & & $\begin{array}{l}\text { Cyrenenmergel der mittleren Saurierschicht, Kitukituki-Bach, } \\
\text { Schlämmrückstand, }<0,2 \mathrm{~mm}>0,1 \mathrm{~mm}\end{array}$ \\
\hline APL & Smeei Beds & Smeei-Schicht, Doanika-Bach \\
\hline AKS & & Grünlicher Schiefer über Smeei-Bank, Tingutinguti-Bach \\
\hline AKT & & Grünlicher Schiefer über Smeei-Bank, Tingutinguti-Bach \\
\hline APH & & $\begin{array}{l}\text { Pseudomonotis-Schiefer über Trigonia smeei-Schicht, } \\
\text { Tingutiguti-Bach südlich von Tendaguru }\end{array}$ \\
\hline AKR & & Smeei-Konglomerat, Tingutinguti-Bach \\
\hline
\end{tabular}


Table 2

Distribution of selected palynomorph species in the Tendaguru Beds. See Table 1 for more sample details.

\begin{tabular}{|c|c|c|c|c|c|c|c|c|c|}
\hline \multirow[b]{2}{*}{ Samples $\rightarrow$} & \multicolumn{4}{|c|}{ Middle Saurian Beds } & \multicolumn{5}{|c|}{ Smeei Beds } \\
\hline & AKA & ALB & $\mathrm{AMB}$ & AMC & APL & AKS & AKT & APH & AKR \\
\hline \multicolumn{10}{|l|}{ Prasinophyta (marine) } \\
\hline 1. Cymatiosphaera $\mathrm{sp}$. & & & & & & $\bullet$ & & & \\
\hline \multicolumn{10}{|l|}{ Dinoflagellates (marine) } \\
\hline 2. Acanthaulax spp. & & & & & & $\bullet$ & & & $\bullet$ \\
\hline 3. Barbatacysta creberbarbata & & & & & & $\bullet$ & $\bullet$ & & $\bullet$ \\
\hline 4. Circulodinium distinctum & & & & & & $\bullet$ & & & \\
\hline 5. Cleistosphaeridium ? spp. & $\bullet$ & & & & & $\bullet$ & $\bullet$ & & $\bullet$ \\
\hline 6. Cometodinium sp. & & & & & & & & & $\bullet$ \\
\hline 7. Dingodinium tuberosum & & & & & $\bullet$ & $\bullet$ & & & $\bullet$ \\
\hline 8. Exochosphaeridium sp. & & & & & & $\bullet$ & & & \\
\hline 9. Kleithr. sp. cf. K. corrugatum & & & & & & & & & $\bullet$ \\
\hline 10. Lithodinia sp. cf. L. jurassica & & & & & & $\bullet$ & & & \\
\hline 11. Lithodinia sp. cf. L. sp. 1 & & & & & & $\bullet$ & & & \\
\hline 12. Meiourogonyaulax sp. C & & & & & & & $\bullet$ & & \\
\hline 13. Mendicodinium ? quadratum & $\bullet$ & $\bullet$ & & & $\bullet$ & & & $\bullet$ & \\
\hline 14. Olig.? sp. cf. $O$. dividuum & & & & & & & & & $\bullet$ \\
\hline 15. Pareodinia angulata & & & & & & & $\bullet$ & & \\
\hline 16. P. sp. cf. P. brevicornuta & & & & & & $\bullet$ & $\bullet$ & & \\
\hline 17. Saeptodinium ? sp. & & & & & & $\bullet$ & $\bullet$ & & $\bullet$ \\
\hline 18. Surculosphaeridium $\mathrm{sp}$. & & & & & & & & & $\bullet$ \\
\hline \multicolumn{10}{|l|}{ Zygnemataceae (freshwater) } \\
\hline 19. Ovoidites parvus & $\bullet$ & $\bullet$ & & & & & & & \\
\hline 20. O. sp. cf. O. microligneolus & $\bullet$ & & & & & & & & \\
\hline \multicolumn{10}{|l|}{ Pteridoph. \& bryoph. spores } \\
\hline 21. Deltoidospora $\mathrm{spp}$ & $\bullet$ & & & $\bullet$ & $\bullet$ & & & $\bullet$ & \\
\hline 22. Matonisporites equiexinus & $\bullet$ & & & & & & & & \\
\hline 23. Todisporites minor & $\bullet$ & $\bullet$ & $\bullet$ & $\bullet$ & & & & & \\
\hline 24. Concavisporites jurienensis & $\bullet$ & & & & & & & & \\
\hline 25. Osmundacidites $\mathrm{sp}$. & & & & $\bullet$ & & & & & \\
\hline 26. Concavissimisporites $\mathrm{sp}$. & $\bullet$ & $\bullet$ & & & & & & & \\
\hline 27. Leptolepidites spp. & $\bullet$ & $\bullet$ & $\bullet$ & $\bullet$ & $\bullet$ & & & & \\
\hline 28. Polycingulatisporites spp. & $\bullet$ & & & & & & & & \\
\hline 29. Foraminisporis dailyi & $\bullet$ & $\bullet$ & & & & & & & \\
\hline 30. Anapiculatisp. dawsonensis & $\bullet$ & $\bullet$ & $\bullet$ & $\bullet$ & & & & & \\
\hline 31. Densoisporites velatus & $\bullet$ & $\bullet$ & $\bullet$ & $\bullet$ & & & & & \\
\hline 32. Klukisporites sp. & $\bullet$ & & & & & & & & \\
\hline \multicolumn{10}{|l|}{ Gymnosperm pollen } \\
\hline 33. Alisporites similis & & $\bullet$ & & & & & & & \\
\hline 34. Alisporites thomasii & & & & & & & & & $\bullet$ \\
\hline 35. A. sp. cf. A. grandis & $\bullet$ & & & & & & & & \\
\hline 36. Alisporites spp. & $\bullet$ & $\bullet$ & & & & $\bullet$ & & & \\
\hline 37. Phrixipollenites sp. & & $\bullet$ & $\bullet$ & $\bullet$ & & & & & \\
\hline 38. Podocarpidites ellipticus & $\bullet$ & $\bullet$ & & $\bullet$ & & & & & \\
\hline 39. P. cf. P. multesimus & $\bullet$ & & & & & & & & \\
\hline 40. Podocarpidites spp. & $\bullet$ & & $\bullet$ & & & & & & \\
\hline 41. Bisaccates indet. & $\bullet$ & $\bullet$ & $\bullet$ & $\bullet$ & $\bullet$ & $\bullet$ & & & $\bullet$ \\
\hline 42. Trisaccites microsaccatus & $\bullet$ & $\bullet$ & & $\bullet$ & & & & & \\
\hline 43. Tr. microsacc. triangul. var. & & & & & & $\bullet$ & $\bullet$ & & \\
\hline 44. Araucariacites australis & $\bullet$ & $\bullet$ & $\bullet$ & & & $\bullet$ & & & \\
\hline 45. Callialasporites dampieri & $\bullet$ & $\bullet$ & & $\bullet$ & & & & & \\
\hline 46. Callialasporites trilobatus & & & & $\bullet$ & $\bullet$ & $\bullet$ & & & $\bullet$ \\
\hline 47. Classopollis spp. & $\bullet$ & $\bullet$ & $\bullet$ & $\bullet$ & $\bullet$ & $\bullet$ & $\bullet$ & $\bullet$ & $\bullet$ \\
\hline
\end{tabular}


ductive enough to be interpreted from a palynological point of view. As usual in tropical areas, weathering is probably the main factor preventing preservation of palynomorphs in a larger number of samples.

A considerable number of additional samples, most of them from the Upper Saurian Beds, yielded hyphae, Rhizophagites and other fungal remains which certainly represent contamination from recent and subrecent sources.

\section{Palynological results}

A comprehensive systematic treatment of the palynomorphs so far recovered from the Tendaguru Beds is beyond the scope of this preliminary report. In the following systematic paragraph selected dinoflagellates are listed alphabetically while some terrestrially-derived miospores are arranged roughly according to morphological criteria, starting with smooth trilete spores and proceeding via several sculptured types to the more complex gymnosperm pollen. Reference to previous records is selective with some emphasis placed on African or southern Gondwanan occurrences to back up the palynostratigraphic discussion below. An alphabetical list of all palynomophs encountered so far in the Tendaguru beds is given in Appen$\operatorname{dix} \mathrm{A}$, and their distribution in the Tendaguru section is depicted in Table 2.

\section{Systematic palynology}

Dinoflagellate cysts in alphabetic order

Barbatacysta creberbarbata (Erkmen \& Sarjeant, 1980) Courtinat, 1989

Plate $1 / 10,11$

Previous records: Callovian-Kimmeridgian, Madagascar (Chen 1978 as Dinoflagellate Form I); topmost Kimmeridgian to earliest Tithonian, Kenya (Jiang et al. 1992); Kimmeridgian, Mada- gascar (Dina 1996); Callovian-Oxfordian, France (Rauscher \& Schmitt 1990); Kimmeridgian to Portlandian, France (Dürr 1988); Oxfordian, Germany (Kunz 1990); Oxfordian to lower Tithonian, Germany (Dürr 1988); Malm alpha, Germany (Brenner 1988).

Dingodinium tuberosum (Gitmez, 1970) Fisher \& Riley, 1980

Plate $1 / 8,9$

Remarks: The present species is closely related to Dingodinium scabratum (Kumar) Lentin \& Williams, 1989 which was originally described from the Kimmeridgian-Tithonian of India (Kumar 1986). D. scabratum is interpreted by Poulsen (1996) as synonym of $D$. minutum Dodekova, 1975

Previous records: Basal Pindiro Shales in the Kizimbani well, southeastern Tanzania, which Balduzzi et al. (1992) interpret as ?Callovian-Oxfordian. Lower Kimmeridgian, Spain (Van Erve et al. 1988); topmost Kimmeridgian to earliest Tithonian, Kenya (Jiang et al. 1992); Kimmeridgian, Madagascar (Dina 1996); latest Oxfordian to Portlandian, Great Britain (Riding \& Thomas 1992).

Lithodinia sp. cf. L. jurassica Eisenack sensu Helby et al., 1988

Plate $1 / 1,2$

Previous records (of L. jurassica): Tithonian, New Zealand (Helby et al. 1988).

\section{Lithodinia sp. cf. L. sp. 1 Davey, 1988}

Plate $1 / 3,4$

Previous records (of L. sp. 1): "Early" Tithonian, Papua New Guinea (Davey 1988).

\section{Meiourogonyaulax sp. C Helby et al., 1988}

Plate $1 / 6,7$

Previous records: Puti Siltstone of New Zealand (Tithonian, Helby et al. 1988).

Plate 1. Marine dinoflagellates from the Smeei Beds $(1-11,13-15)$ and a freshwater alga (12) from the Middle Saurian Beds. All magnifications $\times 1000$. After the sample number the TU Berlin negative number (e.g. IR14 etc.) is always given. 1, 2: Lithodinia sp. cf. L. jurassica Eisenack (sample AKS; IR14, 15). 3, 4: Lithodinia sp. cf. L. sp. 1 Davey (sample AKS; IQ38, 39). 5: Surculosphaeridium sp., operculum (sample AKR; IN30). 6, 7: Meiourogonyaulax sp. C Helby et al. (sample AKT; IS20, 21). 8, 9: Dingodinium tuberosum (Gitmez) Fisher \& Riley (sample AKR; IN8, 9). 10, 11: Barbatacysta creberbarbata (Erkmen \& Sarjeant) Courtinat (sample AKS; IQ15, 16). 12: Ovoidites sp. cf. O. microligneolus Krutzsch, Middle Saurian Beds (sample AKA; IL10). 13: Circulodinium distinctum (Deflandre \& Cookson) Jansonius, Smeei Beds (sample AKS; IQ31). 14: Pareodinia angulata Kumar, Smeei Beds (sample AKT; IS4). 15: Pareodinia sp. cf. P. brevicornuta Kunz sensu Dina, Smeei Beds (sample AKS; IR12, 13) 
2.
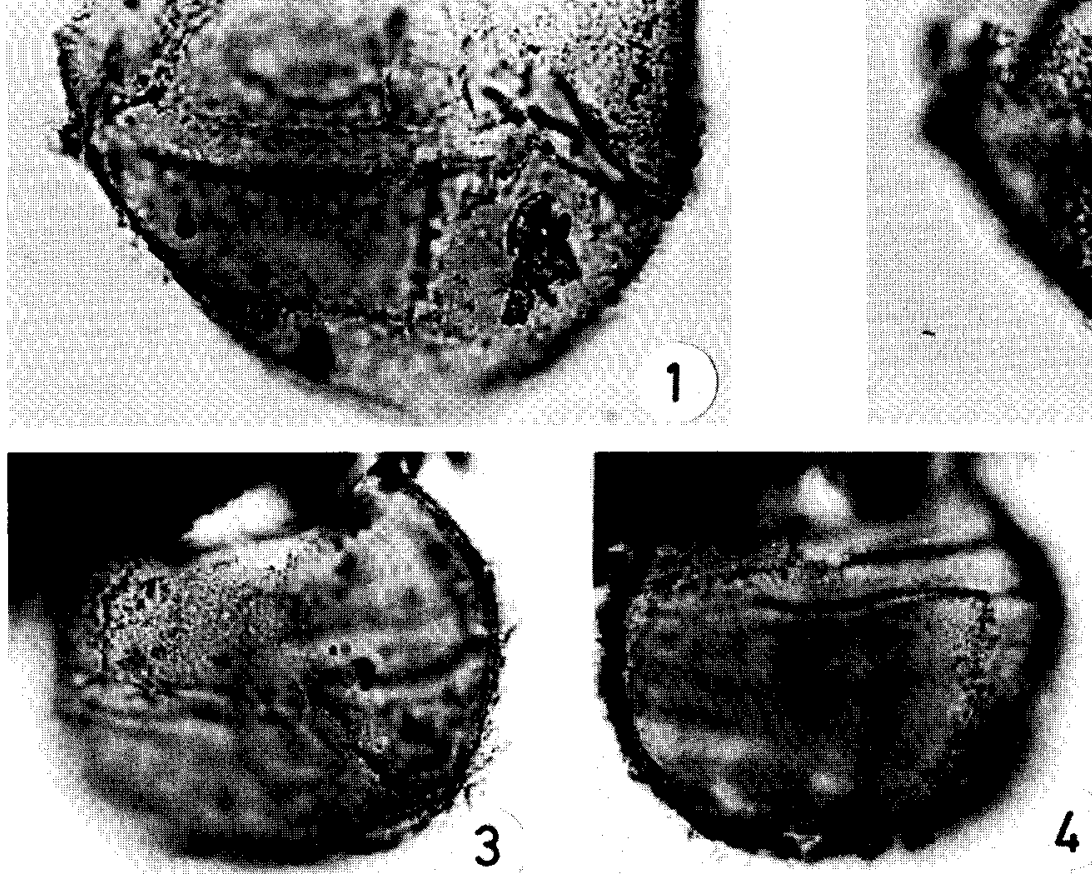

4
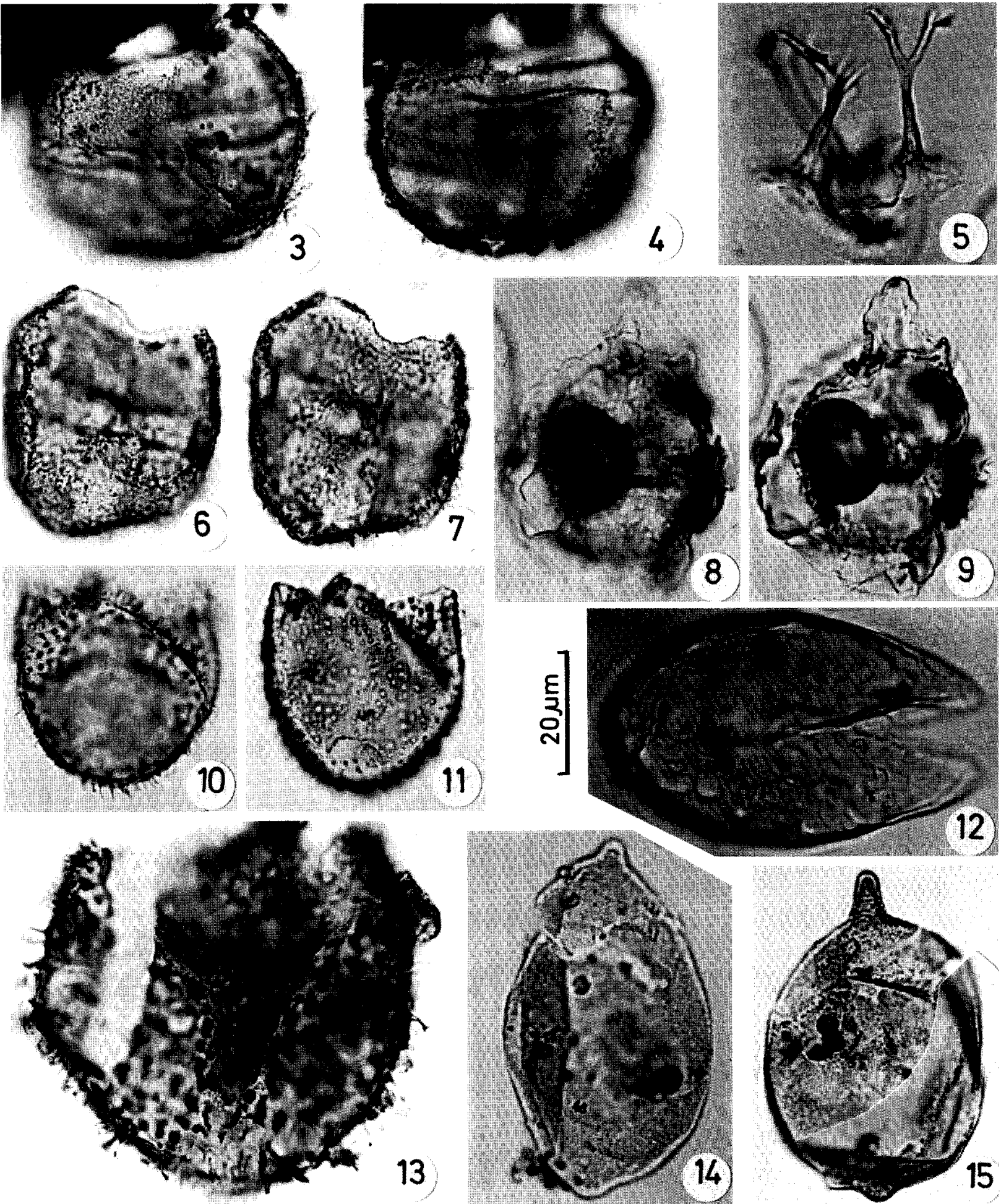


\section{Mendicodinium ? quadratum Kumar, 1987}

Plate 2/1

Remarks: The species $M$. ? quadratum is easily recognizable and so far restricted to a relatively short stratigraphic interval (see below), but its assignment to the genus Mendicodinium and even to the dinoflagellates is questionable. Alternatively it might belong to a different palynomorph group, e.g. Zygnemataceae (freshwater green algae) or to pollen of the Cycadopites type.

Previous records: Lower Kimmeridgian to Tithonian, India (Kumar 1987); middle Oxfordian to Tithonian, Madagascar (Dina 1996); topmost Kimmeridgian to earliest Tithonian, Kenya (Jiang et al. 1992).

Oligosphaeridium ? sp. cf. O. dividuum Williams, 1978

Previous records: (of $O$. dividuum): Valanginian to Barremian, offshore West Africa (Williams 1978).

\section{Pareodinia angulata Kumar, 1987}

Plate $1 / 14$

Remarks: Although many authors regard the presence of an intercalary archaeopyle as diagnostic for the genus Pareodinia, illustrations of Parodinia specimens exhibiting a different, possibly apical archaeopyle are not uncommon in the literature (e.g. Pareodinia sp. Davey 1982, Aptian, Germany; Pareodinia sp. I sensu Leereveld 1995, Lower Cretaceous, Spain; P. ceratophora sensu Conway 1990, Bathonian, Israel). Courtinat (1989) emphasises the variability in the number of paraplates in Pareodinia and tentatively interprets the archaeopyle of the type species, $P$. ceratophora, as apical. Lentin \& Vozzhennikova (1990) note that the holotype of the type species does not exhibit an archaeopyle at all and thus prefer to use the genus Pareodinia for forms without archaeopyle. Under consideration of this situation, forms with apical archaeopyle (Plate 1/14: $P$. angulata) and with unclear archaeopyle type (Plate 1/15: Pareodinia sp. cf. P. brevicornuta) are included in Pareodinia in the present paper. Kumar (1987) described the archaeopyle of $P$. angulata as intercalary, which is, however, not supported by his photographic illustrations.

Previous records: Lower Kimmeridgian to Tithonian, India (Kumar 1987).

Pareodinia sp. cf. P. brevicornuta Kunz, 1990 sensu Dina, 1996

Plate $1 / 15$

Remarks: This species is closely related to shorth-horned varieties of Pareodinia ceratophora Deflandre, 1947 as illustrated e.g. by Dürr (1988, plate 6, fig. 7, Oxfordian to lower Tithonian of Germany; Kimmeridgian to Portlandian, France) and Conway (1990, plate 17, fig. 1, Bathonian, Israel). A special feature in some Tendaguru cysts is the presence of a short, round, antapical knob, probably a rudimentary antapical horn. This feature also occurs in the $P$. ceratophora specimen from Israel mentioned above.

Another closely related species is Kalyptea sp. cf. K. monoceras Cookson \& Eisenack, 1960 (Norvick \& Burger, 1975, plate 12, fig. 2) from the Cenomanian of Australia.

Previous records of $P$. brevicornuta: Callovian, Madagascar (Dina 1996); Tithonian, Germany (Kunz 1990).

\section{Zygnemataceae (freshwater algae)}

Ovoidites parvus (Cookson \& Dettmann, 1959) Nakoman, 1966

Plate $2 / 2$

Previous records: Upper Tithonian to lower Aptian, Australia (Backhouse 1988, p. 111); Stanleyville Group, Zaire, near the Jurassic-Cretaceous border (Maheshwari et al. 1977, p. 56); Lower Cretaceous, Egypt (Schrank \& Mahmoud 1998); Albian, Canada (Zippi 1998); Eocene, California (Frederiksen et al. 1983).

Botanical affinity: Zygospores of Spirogyra and Zygogonium, Zygnemataceae, freshwater algae (Zippi 1998).

Plate 2. Palynomorphs from the Middle Saurian Beds (1-10, 12-14) and from the Smeei Beds (11). All magnifications $\times 1000$. 1: Mendicodinium ? quadratum Kumar (sample AKA; IM29). 2: Ovoidites parvus (Cookson \& Dettmann) Nakoman (sample ALB; IU17). 3: Densoisporites velatus Weyland \& Krieger (sample ALB; IT25). 4: Foraminisporis dailyi (Cookson \& Dettmann) Dettmann (sample AKA; IM31). 5-7: Anapiculatisporites dawsonensis Reiser \& Williams (sample AKA; IJ6). 8, 9: Matonisporites equiexinus Couper (sample AKA; IM8, 9). 10: Concavisporites jurienensis Balme (sample AKA; IL21). 11: Alisporites thomasii (Couper) Nilsson, (sample AKR; IN37). 12: Podocarpidites cf. P. multesimus (Bolkhovitina) sensu Dettmann (sample AKA; IM33). 13: Phrixipollenites sp. Volkheimer et al. (sample ALB; IT29). 14: Alisporites sp. cf. A. grandis (Cookson) Dettmann (sample AKA; IM22) 

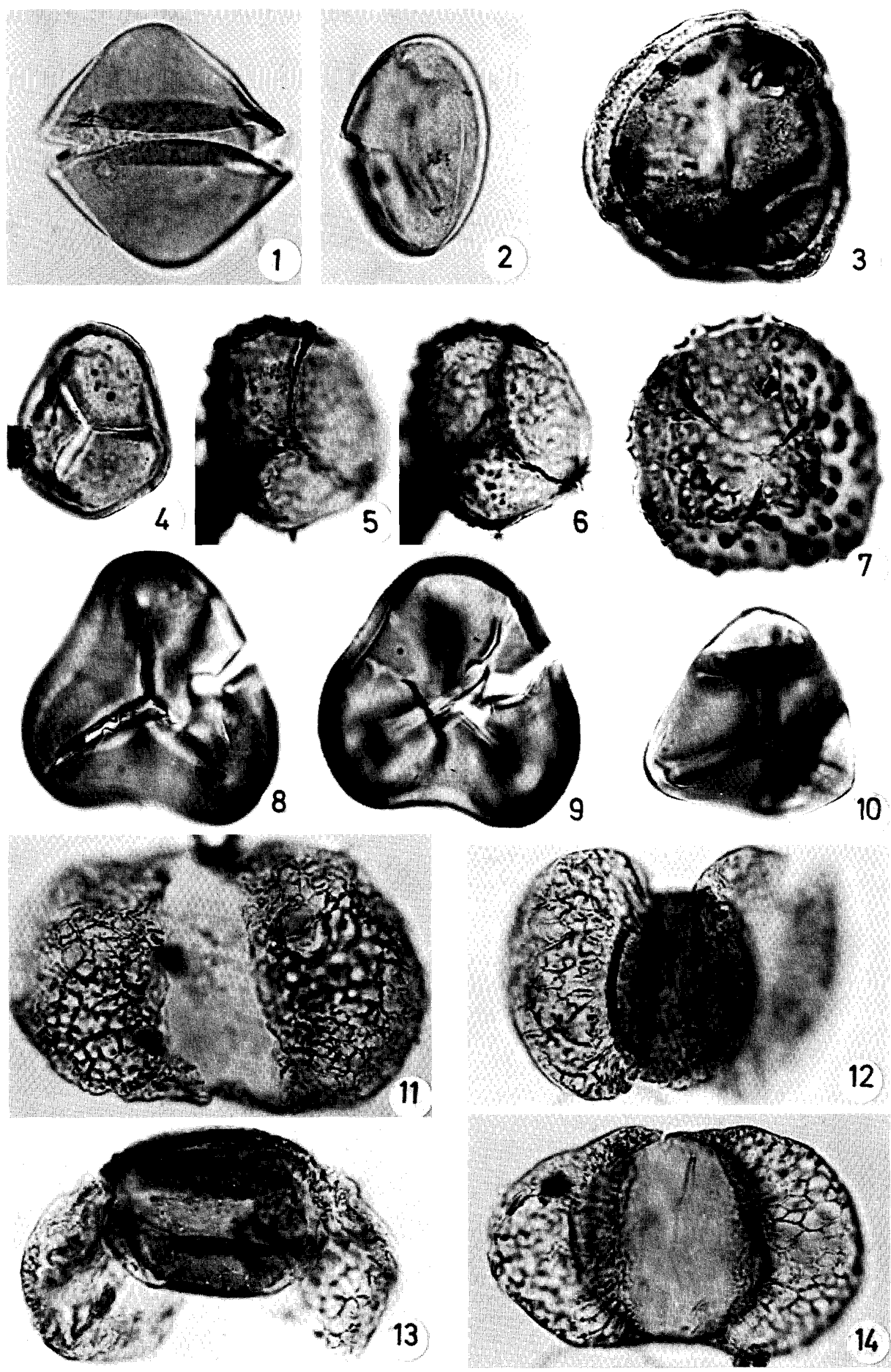
Pteridophytic and bryophytic spores

Note: Throughout this paper the term bryophytic spores is meant to include the spores of hornworts and liverworts, that is bryophytes in the sense of e.g. Taylor \& Taylor (1993).

Foraminisporis dailyi (Cookson \& Dettmann, 1958) Dettmann, 1963

Plate 2/4

Previous records: Tithonian-Aptian, Australia (Backhouse 1988); Berriasian to Albian, Australia; Barremian to Aptian, Argentina; Barremian to Albian, U.S.A. (Archangelsky \& Gamerro 1967).

Botanical affinity: Similar to spores of the hepatics Phaeoceras bulbiculosus and Nothylas breutelii (Dettmann 1963).

Anapiculatisporites dawsonensis Reiser \& Williams, 1969

Plate $2 / 5-7$

Previous records: Mkuju Formation (Rhaetian), Luwegu Basin, Tanzania (Hankel 1987); Lower Jurassic to lower Kimmeridgian, Kizimbani well, southeastern Tanzania (Balduzzi et al. 1992); upper Bathonian to Callovian, Madagascar (Dina 1996); Early Cretaceous, Congo (Dejax 1987).

Densoisporites velatus Weyland \& Krieger, 1953

Plate 2/3

Previous records: Rhaetian to Senonian, widespread (Srivastava 1987).

Botanical affinities: Selaginellites polaris Lundblad (Dettmann 1963).

Gymnosperm pollen

Alisporites similis (Balme, 1957) Dettmann, 1963

Plate $3 / 4$

Previous records: Kimmeridgian, Madagascar (Dina 1996); late Toarcian to early Bajocian, Australia (McKellar 1974); upper Kimmeridgian to Aptian, Australia (Backhouse 1988).
Phrixipollenites sp. Volkheimer et al., 1977

Plate 2/13

Previous records: Hauterivian to Barremian, Argentina (Volkheimer et al. 1977).

\section{Podocarpidites ellipticus Cookson, 1947}

\section{Plate $3 / 2,3$}

Previous records: Middle Oxfordian, Madagascar (Dina 1996); Upper Cretaceous, offshore South Africa (McLachlan \& Pieterse 1978); Tertiary, Kerguelen Archipelago (Cookson 1947).

Trisaccites microsaccatus (Couper, 1953) Couper, 1960

Plate $3 / 10-12$

Remarks: A closely related or identical form is Trisaccites variabilis (Sukh Dev) Haskell, 1968, from the Jurassic of Australia (McKellar 1974, pl. 10, fig. 12).

Previous records: Upper Jurassic, Lower Cretaceous, Lower Tertiary, Australia (Burger 1980); upper Bathonian to Callovian of Madagascar (Dina 1996, plate 2, fig. 22 as Microcachryidites antarcticus).

Trisaccites microsaccatus (Couper, 1953) Couper, 1960, sensu Volkheimer et al. (1977), triangular variety

Plate 3/14-16

Previous records: Hauterivian to Barremian, Argentina (Volkheimer et al. 1977); Callovian to Albian, Argentina (Volkheimer \& Quattrocchio 1981).

Botanical affinities: Podocarpaceae (Gamerro 1965).

Callialasporites dampieri (Balme, 1957) Sukh Dev, 1961

Plate $3 / 7,8$

Previous records: Lias to Kimmeridgian, Sahara (Reyre 1973); worldwide Bajocian to Lower Cretaceous (Srivastava 1987).

Botanical affinity: As for C. trilobatus.

Plate 3. Pollen from the Middle Saurian Beds (2-5, 7-13) and from the Smeei Beds $(1,6,14-16)$. All magnifications $\times 1000$. 1: Araucariacites australis Cookson (sample AKS; IR27), 2, 3: Podocarpidites ellipticus Cookson (sample ALB; IT36, 37). 4: Alisporites similis (Balme) Dettmann (sample ALB; IT16). 5: Callialasporites trilobatus (Balme) Sukh Dev (sample AMC; IV31). 6: Callialasporites trilobatus (Balme) Sukh Dev (sample AKS; IQ2). 7, 8: Callialasporites dampieri (Balme) Sukh Dev (sample AKA; IK23, 24). 9, 13: Classopollis spp., tetrad (sample AKA; IJ2, 4). 10, 11: Trisaccites microsaccatus (Couper) Couper (sample AKA; IM10, 11). 12: Trisaccites microsaccatus (Couper) Couper (sample ALB; IU12). 14-16: Trisaccites microsaccatus (Couper) Couper sensu Volkheimer et al., triangular variety (sample AKT; IS 9, 10, 11) 


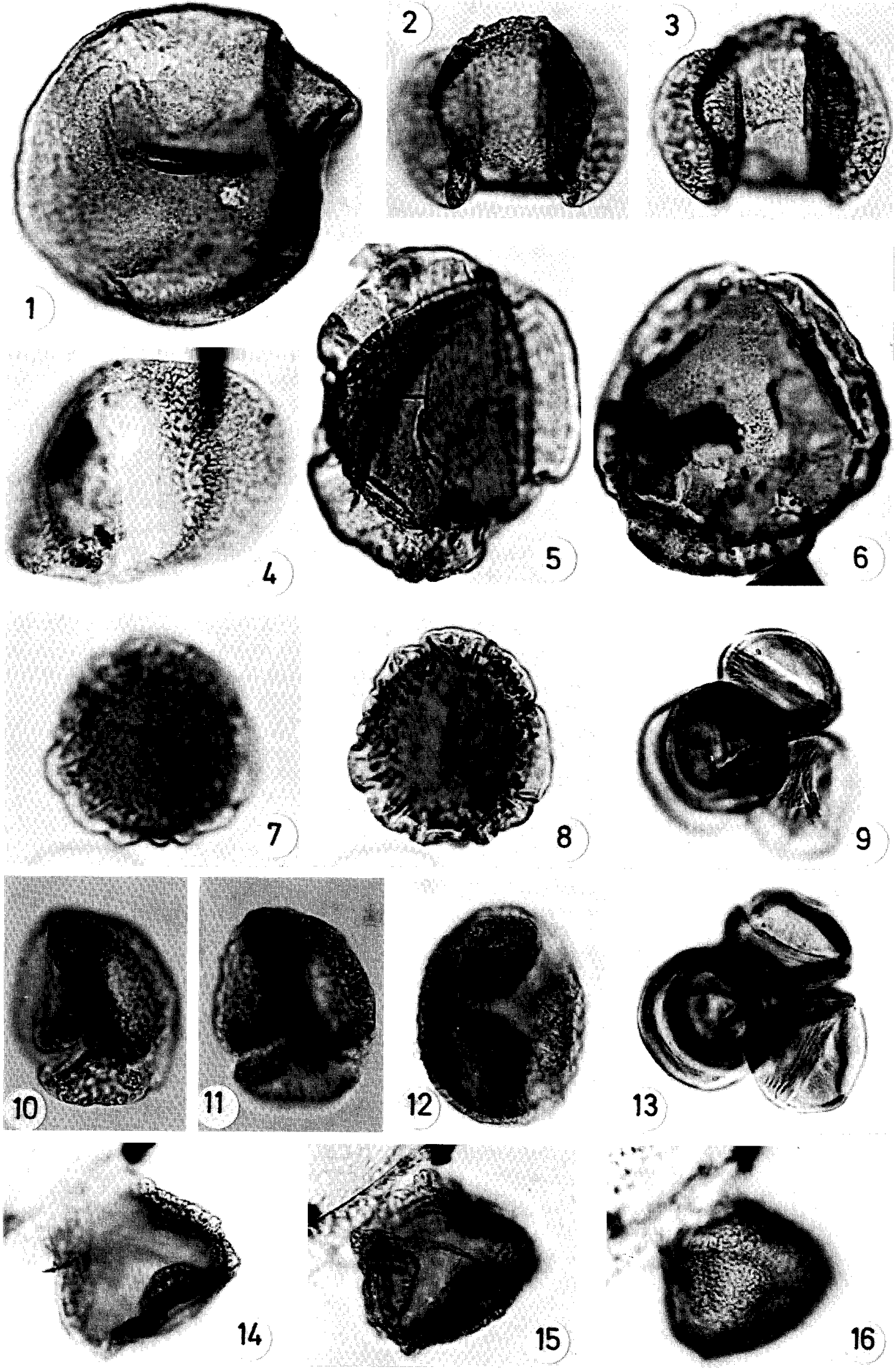


Callialasporites trilobatus (Balme, 1957) Sukh Dev, 1961

Plate $3 / 5,6$

Previous records: "Infralias" to Upper Jurassic (?), Sahara (Reyre 1973); worldwide Middle Jurassic to Lower Cretaceous (Srivastava 1987).

Botanical affinity: More likely Araucariaceae than Podocarpaceae (Batten \& Dutta 1997).

Distribution of palynomorphs

in the Tendaguru Beds

The distribution of selected palynomorph species in the Tendaguru Beds is shown in Table 2. From this overview it is evident that the Middle Saurian Beds and the Smeei Beds yielded two rather different palynofloras which are here informally designated as (1) Anapiculatisporites-Densoisporites-Trisaccites assemblage and (2) BarbatacystaPareodinia assemblage, respectively.

The Anapiculatisporites-Densoisporites-Trisaccites assemblage from the Middle Saurian Beds is dominated by terrestrially-derived miospores with pteridophytic and bryophytic elements attaining a similar degree of diversity as the gymnosperm pollen. Among the aquatic palynomorphs, marine dinoflagellates are rare or questionable, and freshwater algae (Ovoidites, Zygnemataceae) are present.

In contrast to this, the Barbatacysta-Pareodinia assemblage from the Smeei Beds contains common marine dinoflagellates, while freshwater algae, pteridophytic and bryophytic spores are rare or absent. Among the terrestrially-derived miospores, gymnosperm pollen are represented by bisaccates, Araucariacites, Callialasporites, and particularly Classopollis. Classopollis tends to be abundant or dominant in most productive samples from the Tendaguru Beds.

A third palynoflora, the Rhizophagites assemblage mainly from the Upper Saurian Beds, is characterized by the presence of hyphae and other fungal remains, which may be associated with rare conifer (bisaccates) and angiosperm pollen (tricolpates, tricolporates, triporates). Rhizophagites is known to be a major contaminant of palynological surface samples from carbonates and limy soils (Wood et al. 1996). Therefore the Rhizophagites assemblage is regarded as contaminated from recent and subrecent sources, and no further interpretation is attempted. The presence of rare angiosperm pollen makes the Rhizophagites assemblage comparable with the palynoflora that Jarzen (1981) reported from his only productive sample, likewise from the Upper Saurian Beds.

\section{Palynostratigraphic results}

The combined ranges of Barbatacysta creberbarbata, Dingodinium tuberosum, Mendicodinium ? quadratum and Pareodinia angulata suggest a Kimmeridgian to Tithonian age for the Barbatacysta-Pareodinia assemblage and therefore for the Smeei Beds. Among the palynomorphs mentioned, only Mendicodinium ? quadratum was also encountered in the Middle Saurian Beds. Its records from India (ammonite-dated Lower Kimmeridgian to Tithonian, Kumar 1987) and Kenya (topmost Kimmeridgian to earliest Tithonian, Jiang et al. 1992) suggest that this species may be a potential Kimmeridgian-Tithonian marker although it is reported to range down to the middle Oxfordian in Madagascar (Dina 1996).

The pollen and spores of the Anapiculatisporites-Densoisporites-Trisaccites assemblage are generally stratigraphically long-ranging (Jurassic to Lower Cretaceous or even Tertiary) and offer little additional biostratigraphic information on the age of the Middle Saurian Beds.

The composition of this assemblage suggests broad correlation with the upper part of the Callialasporites dampieri Superzone (Murospora florida Zone, Oxfordian-Kimmeridgian) and the lower part of the Microcachryidites Superzone (Retitriletes watherooensis Zone, Tithonian) of Australia (Helby et al. 1987). The Anapiculatisporites-Densoisporites-Trisaccites assemblage also shows some similarity with terrestrial palynomorph assemblages from the Tithonian of Argentina (Volkheimer \& Quattrocchio 1975) which Quattrocchio et al. (1996) place in the Microcachryidites antarcticus Zone.

The dinoflagellate age of the Smeei Beds given above is in good agreement with their late Kimmeridgian to Tithonian ammonite age postulated by Zwierzycki (1914). However, Zils et al. (1995) adopt a slightly older age for the Smeei Beds after indentifying the ammonite Aspidoceras richthofe$n i$ which they consider to be Middle Kimmeridgian in age because Gröschke \& Kapilima (1995) reported this species from beds of the same age near Nchia, southern Tanzania. If correct then the latter age determination would imply an age not younger than Middle Kimmeridgian for the Anapiculatisporites-Densoisporites-Trisaccites assemblage and for the Barbatacysta-Pareodinia assemblage. From a palynostratigraphic point of view this can be neither confirmed nor rejected. 


\section{Palaeoecological conclusions}

The abundance of dinoflagellates in the Smeei Beds indicates deposition in a marine environment. Scarcity or absence of dinoflagellates in the Middle Saurian Beds together with the presence there of freshwater algae and dominance of terrestrially-derived miospores suggest an aquatic environment with strong influx from a terrestrial source and questionable marine influence. Influx of terrestrially-derived palynomorphs into the Smeei Beds was relatively low and mainly confined to a few conifer pollen types. Pteridophytic and bryophytic spores, which mainly represent the vegetation growing close to the aquatic depositional sites, are absent or very subordinate in the Smeei Beds. This may be related to transport sorting or to other local factors such as drowning by the sea of the fluviocoastal plain environments where the pteridophytic-bryophytic communities existed during the time of deposition of the Middle Saurian Beds.

A conifer vegetation, mainly Cheirolepidaceae, Podocarpaceae and Araucariaceae was predominant on the topographically higher and relatively dry environments, which would be less affected by an advancing sea.

If the Tendaguru palynofloras are compared on a larger scale with Late Jurassic miospore assemblages elsewhere in the world, the following points may be emphasised. Closest palaeobiogeographical links exist with Southern Gondwanan regions such as Madagascar, Australia, Argentina and India. The relatively low diversity of the pteridopyhtic-bryophytic element and the abundance of Classopollis even in the palynofloras from the Middle Saurian Beds is remarkable. Classopollis producers (Cheirolepidaceae, see Traverse 1988) are commonly regarded as xerophytic. Under consideration of the palaeocontinental position of Tendaguru on the huge Gondwana Continent in the southern dry zone, this may be taken as evidence for prevailing semiarid conditions with pronounced dry seasons during the time of deposition of the Tendaguru Beds.

\section{Acknowledgements}

I am grateful to Dr. W.-D. Heinrich for making available samples from the Tendaguru collections of the Museum für Naturkunde (Berlin) and for relevant informations. Technical help from M. Baudisch, D. Machander (HF laboratory), H. Glowa, B. Kleeberg (photographic laboratory) and B. Dunker (drawings) is gratefully acknowledged. Thanks are also due to the German Research Foundation (DFG) for financi- al support and, last not least, to Dr. G. F. W. Herngreen, Haarlem, for discussions (in 1992) of problems related to Tendaguru palynology.

\section{References}

Aitken, W. G. 1961. Geology and palaeontology of the Jurassic and Cretaceous of Southern Tanganyika. - Geological Survey of Tanganyika Bulletin 31: 1-144.

Archangelsky, S. \& Gamerro, J. C. 1967. Spore and pollen types of the Lower Cretaceous in Patagonia (Argentina). - Review of Palaeobotany and Palynology 1: 211-217.

Backhouse, J. 1988. Late Jurassic and Early Cretaceous palynology of the Perth Basin, Western Australia. - Geological Survey of Western Australia Bulletin 135: i-vi, $1-233$.

Balduzzi, A., Msaky, E., Trincianti, E. \& Manum, S. B. 1992. Mesozoic Karoo and post-Karoo formations in the Kilwa area, southeastern Tanzania - a stratigraphic study based on palynology, micropalaeontology and well $\log$ data from the Kizimbani well. - Journal of African Earth Sciences 15 (3/4): 405-427.

Batten, D. J. \& Dutta, R. J. 1997. Ultrastructure of exine of gymnospermous pollen grains from Jurassic and basal Cretaceous deposits in Northwest Europe and implications for botanical relationships. - Review of Palaeobotany and Palynology 99: 25-54.

Brenner, W. 1988. Dinoflagellaten aus dem Unteren Malm (Oberer Jura) von Süddeutschland; Morphologie, Ökologie, Stratigraphie. - Tübinger Mikropaläontologische Mitteilungen 6: 1-116.

Burger, D. 1980. Palynology of the Lower Cretaceous in the Surat Basin. - Bureau of Mineral Resources, Geology and Geophysics Bulletin 189: i-v, 1-106.

Chen, Yow-yuh 1978. Jurassic and Cretaceous palynostratigraphy of a Madagascar well. - 264 pp., Dissertation, Department of Geosciences, University of Arizona.

Conway, B. H. 1990. Paleozoic-Mesozoic palynology of Israel. II. Palynostratigraphy of the Jurassic succession in the subsurface of Israel. - Geological Survey of Israel Bulletin 82: 1-39.

Cookson, I. C. 1947. Plant microfossils from the lignites of Kerguelen Archipelago. - B.A.N.Z. Antarctic Research Expedition 1929-1931, Reports-Series A (edited by Douglas Mawson) vol. II (Geology), pt. 8: 129-142, The Hassell Press, Adelaide.

Courtinat, B. 1989. Les organoclastes des formations lithologiques du Malm dans le Jura méridional. Systématique, biostratigraphie et éléments d'interprétation paléoécologique. - Documents des Laboratoires de Géologie Lyon 105: $1-361$.

Davey, R. J. 1982. Die Verbreitung der Palynomorphen im späten Apt und frühen Alb Nordwestdeutschlands. Geologisches Jahrbuch A65: 365-403.

- 1988. Palynological zonation of the Lower Cretaceous, Upper and uppermost Middle Jurassic in the northwestern Papuan Basin of Papua New Guinea. - Geological Survey of Papua, New Guinea, Memoir 13: 1-77.

Dejax, J. 1987. Une étude palynologique dans le Crétacé inférieur du Congo. - 187 pp., Thèse Université Paris 6.

Dettmann, M. E. 1963. Upper Mesozoic microfloras from southeastern Australia. - Proceedings Royal Society of Victoria 77 (1): 1-148

Dina, A. 1996. Geologie und jurassische Palynologie des südlichen Morondava-Beckens, Madagaskar. - 137 pp., Dissertation, Technische Universität Berlin.

Dürr, G. 1988. Palynostratigraphie des Kimmeridgium und Tithonium von Süddeutschland und Korrelation mit borealen Floren. - Tübinger Mikropaläontologische Mitteilungen 5: 1-159. 
Frederiksen, N. O., Carr, D. R., Lowe, G. D. \& Wosika, E. P. 1983. Middle Eocene palynomorphs from San Diego, California. - AASP Contributions Series 12: 1-154, American Association of Stratigraphic Palynologists.

Gamerro, J. C. 1965. Morfología del polen de la conífera Trisacocladus tigrensis Archang. de la Formación Baqueró, Provincia de Santa Cruz. - Ameghiniana 4 (1): 31-38.

Gröschke, M. \& Kapilima, S. 1995. Ammoniten aus dem Septarienmergel (Kimmeridgium) des Mandawa-MahokondoGebietes bei Nchia, Südtansania. - Berliner geowissenschaftliche Abhandlungen, Reihe E 16, GundolfErnst-Festschrift: $645-661$.

Hankel, O. 1987. Die Stratigraphie der Karoo-Sequenz des Luwegu-Beckens, Tansania. - Berliner geowissenschaftliche Abhandlungen, Reihe A 78: 49-110.

Helby, R., Morgan, R. \& Patridge, A. D. 1987. A palynological zonation of the Australian Mesozoic. - Memoir of the Association of Australasian Palaeontologists 4: 1-94.

Helby, R, Wilson, G. J. \& Grant-Mackie, J. A. 1988. A preliminary biostratigraphic study of Middle to Late Jurassic dinoflagellate assemblages from Kawhia, New Zealand. Memoir Association of Australasian Palaeontologists 5: $125-166$.

Janensch, W. 1914. Die Gliederung der Tendaguruschichten im Tendagurugebiet und die Entstehung der Saurierlagerstätten. - Archiv für Biontologie 3 (3), Wissenschaftliche Ergebnisse der Tendaguru-Expedition 1909-1912, Zweiter Teil: 225-261, Friedländer \& Sohn, Berlin.

Jarzen, D. M. 1981. A preliminary report on the palynomorphs recovered from Tendaguru Hill (Tanzania). Pollen et Spores 23: 149-163.

Jiang, Q., Mungai, M. W., Downie, C. \& Neves, R. 1992. Late Jurassic dinoflagellate assemblages of the Mto Panga Quarry, Mombasa, Kenya. - Review of Palaeobotany and Palynology 74: 77-100.

Kent, P. E., Hunt, M. A. \& Johnstone, M. A. 1971. The geology and geophysics of coastal Tanzania. - Institute of Geological Sciences Geophysical Paper 6: i-vi, 1-101.

Kumar, A. 1986. A dinocyst assemblage from the Middle Member (Lower Kimmeridgian-Tithonian) of the Jhuran Formation, Kachchh, India. - Review of Palaeobotany and Palynology 48: 377-407.

- 1987. Additional dinocysts and acritarchs from the Middle Member (Lower Kimmeridgian-Tithonian) of the Jhuran Formation, Kachchh, India. - Revista Española de Micropaleontología 19 (2): 239-249.

Kunz, R. 1990. Phytoplankton und Palynofazies im Malm NW-Deutschlands (Hannoversches Bergland). - Palaeontographica, Abt. B 216 (1-4): 1-105.

Leereveld, H. 1995. Dinoflagellate cysts from the Lower Cretaceous Río Argos succession (SE Spain). - LPP Contribution Series 2: 1-175, Laboratory of Palaeobotany and Palynology Foundation, Utrecht.

Lentin, J. K. \& Vozzhennikova, T. F. 1990. Fossil dinoflagellates from the Jurassic, Cretaceous and Paleogene deposits of the USSR - a re-study. - AASP Contributions Series 23: i-v, 1-220, American Association of Stratigraphic Palynologists.

Maheshwari, H. K., Bose, M. N. \& Kumaran, K. P. N. 1977. Mesozoic sporae dispersae from Zaïre. III. - Some miospores from the Stanleyville Group. - Koninklijk Museum voor Midden-Afrika Annalen, Reeks in $8^{\circ}$, Geologische Wetenschappen 80: 45-60.

McKellar, J. L. 1974. Jurassic miospores from the upper Evergreen Formation, Hutton Sandstone, and basal Injune Creek Group, north-eastern Surat Basin. - Geological Survey of Queensland Publication 361 = Palaeontological Papers 35: 1-50.

McLachlan, I. R. \& Pieterse, E. 1978. Preliminary palynological results: site 361, leg 40, Deep Sea Drilling Project. Initial Reports of the Deep Sea Drilling Project 40: 857-881.

Norvick, M. S. \& Burger, D. 1975. Palynology of the Cenomanian of Bathurst Island, Northern Territory, Australia.
- Bureau of Mineral Resources, Geology and Geophysics Bulletin 151: $1-169$.

Poulsen, N. E. 1996. Dinoflagellate cysts from marine Jurassic deposits of Denmark and Poland. - American Association of Stratigraphic Palynologists Contributions Series 31: $1-227$

Quattrocchio, M. E., Sarjeant, W. A. S. \& Volkheimer, W. 1996. Marine and terrestrial Jurassic microfloras of the Neuquén Basin (Argentina): palynological zonation. GeoResearch Forum 1-2: 167-178.

Rauscher, R. \& Schmitt, J.-P. 1990. Recherches palynologiques dans le Jurassique d'Alsace (France). - Review of Palaeobotany and Palynology 62: 107-156.

Reyre Y. 1973. Palynologie du Mésozoique Saharien. Mémoires du Muséum National d'Histoire Naturelle, Nouvelle Série, Série C 27: 1-284.

Riding, J. B. \& Thomas, J. E. 1992. Dinoflagellate cysts of the Jurassic System. In Powell, A. J. (ed.): A Stratigraphic Index of Dinoflagellate Cysts: 7-98, Chapman \& Hall, London.

Russell, D., Béland, P. \& McIntosh, J. S. (1980): Paleoecology of the dinosaurs of Tendaguru (Tanzania). - Mémoires de la Société géologique de France, N.S. 139: 169-175.

Schrank, E. \& Mahmoud, M. S. 1998. Palynology (pollen, spores and dinoflagellates) and Cretaceous stratigraphy of the Dakhla Oasis, central Egypt. - Journal of African Earth Sciences 26 (2): 167-193.

Srivastava, S. K. 1987. Jurassic spore-pollen assemblages from Normandy (France) and Germany. - Geobios 20 (1): $5-79$

Taylor, T. N. \& Taylor, E. L. 1993. The biology and evolution of fossil plants. - 982 S., Prentice Hall, Englewood Cliffs, New Jersey.

Traverse, A. 1988: Paleopalynology. 600 S., Unwin Hyman, Boston.

Van Erve, A. W., Besems, R. E. \& Love, C. F. 1988. A palynological investigation of some Lower Kimmeridgian deposits from Spain. - Journal of Micropalaeontology 7 (2): $217-232$.

Volkheimer, W. \& Quattrocchio, M. 1975. Palinologia estratigrafica del Titoniano (Formacion Vaca Muerta) en el area de Caichigüe (Cuenca Neuquina). - Ameghiniana 12 (3): $193-241$.

- 1981. Distribucion estratigrafica de los palinomorfos Jurásicos y Cretácicos en la Faja Andina y areas adyacentes de América del Sur Austral con especial consideracion de la Cuenca Neuquina. - Comité Sudamericano del Jurásico y Cretácico: Cuencas sedimentarias del Jurásico y Cretácico de América del Sur 2: 407-444, Buenos Aires.

Volkheimer, W., Caccavari De Felice, M. A. \& Sepulveda, E. 1977. Datos palinológicos de la Formación Ortiz (Grupo La Amarga), Cretácico inferior de la Cuenca Neuquina (Republica Argentina). - Ameghiniana 14 (1-4): 59-74.

Williams, G. L. 1978. Palynological biostratigraphy, Deep Sea Drilling Project sites 367 and 370. - Initial Reports of the Deep Sea Drilling Project 41: 783-815.

Wood, G. D., Gabriel, A. M. \& Lawson, J. C. 1996. Palynological techniques - processing and microscopy. In Jansonius, J \& McGregor, D.C. (eds.): Palynology: principles and applications 1: 29-50, American Association of Stratigraphic Palynologists Foundation.

Zils, W., Werner, C., Moritz, A. \& Saanane, C. 1995. Tendaguru, the most famous dinosaur locality of Africa. Review, survey and future prospects. - Documenta naturae 97: $1-41$.

Zippi, P. A. 1998. Freshwater algae from the Mattagami Formation (Albian), Ontario: Paleoecology, botanical affinities, and systematic taxonomy. - Micropaleontology $\mathbf{4 4}$ (suppl. 1): 1-78.

Zwierzycki, J. 1914. Die Cephalopodenfauna der TendaguruSchichten in Deutsch-Ostafrika. - Archiv für Biontologie 3 (4), Wissenschaftliche Ergebnisse der Tendaguru-Expedition 1909-1912, Dritter Teil: 7-96, Friedländer \& Sohn, Berlin. 
Appendix A.

Alphabetical index of palynomorph species with reference to plate figures and to position in the range chart (number in Table 2).

$\longrightarrow$ Plate $\quad$ No.

\section{Phytoplankton species}

Acanthaulax spp.

Barbatacysta creberbarbata (Erkmen \& Sarjeant, 1980) Courtinat, 1989

Circulodinium distinctum (Deflandre \& Cookson, 1955) Jansonius, 1986

Cleistosphaeridium ? spp.

Cometodinium sp. Chen, 1978

Cymatiosphaera sp.

Dingodinium tuberosum (Gitmez, 1970) Fisher \& Riley, 1980

Exochosphaeridium sp.

Kleithriasphaeridium sp. cf. K. corrugatum Davey, 1974

Lithodinia sp. cf. L. jurassica Eisenack sensu Helby et al., 1988

Lithodinia sp. cf. L. sp. 1 Davey, 1988

Meiourogonyaulax sp. C Helby et al., 1988

Mendicodinium ? quadratum Kumar, 1987

Oligosphaeridium ? sp. cf. O. dividuum Williams, 1978

Ovoidites parvus (Cookson \& Dettmann, 1959) Nakoman, 1966

Ovoidites sp. cf. O. microligneolus Krutzsch, 1959

Pareodinia angulata Kumar, 1987

Pareodinia sp. cf. P. brevicornuta Kunz, 1990 sensu Dina, 1996

Saeptodinium? sp.

Surculosphaeridium sp.

$\begin{array}{ll} & 2 \\ 1 / 10,11 & 3 \\ 1 / 13 & 4 \\ & 5 \\ & 6 \\ 1 / 8,9 & 1 \\ & 7 \\ & 8 \\ 1 / 1,2 & 9 \\ 1 / 3,4 & 10 \\ 1 / 6,7 & 11 \\ 2 / 1 & 12 \\ & 13 \\ 2 / 2 & 14 \\ 1 / 12 & 19 \\ 1 / 14 & 20 \\ 1 / 15 & 15 \\ & 16 \\ 1 / 5 & 17 \\ & 18\end{array}$

\section{Miospore species}

Alisporites similis (Balme, 1957) Dettmann, 1963

Alisporites thomasii (Couper, 1958) Nilsson, 1958

Alisporites sp. cf. A. grandis (Cookson, 1953) Dettmann, 1963

Alisporites spp.

Anapiculatisporites dawsonensis Reiser \& Williams, 1969

Araucariacites australis Cookson, 1947

Bisaccates indet.

Callialasporites dampieri (Balme, 1957) Sukh Dev, 1961

Callialasporites trilobatus (Balme, 1957) Sukh Dev, 1961

Classopollis spp.

Concavisporites jurienensis Balme, 1957

Concavissimisporites sp.

Deltoidospora spp.

Densoisporites velatus Weyland \& Krieger, 1953

Foraminisporis dailyi (Cookson \& Dettmann, 1958) Dettmann, 1963

Klukisporites sp.

Leptolepidites spp.

Matonisporites equiexinus Couper, 1958

Osmundacidites sp.

Phrixipollenites sp. Volkheimer et al., 1977

Podocarpidites ellipticus Cookson, 1947

Podoc. cf. P. multesimus (Bolkh.) Pocock, sensu Dettmann (1963)

$3 / 4$

$2 / 11$

$2 / 14$

$2 / 5-7$

$3 / 1$

$3 / 7,8$

$3 / 5,6$

$3 / 9,13$

$2 / 10$

Podocarpidites spp.

Polycingulatisporites spp.

Todisporites minor Couper, 1958

Trisaccites microsaccatus (Couper, 1953) Couper, 1960

Trisaccites microsaccatus sensu Volkheimer et al. (1977), triangular variety

$\begin{array}{ll}2 / 10 & 24 \\ & 26 \\ 2 / 3 & 21 \\ 2 / 4 & 31 \\ & 29 \\ & 32 \\ 2 / 8,9 & 27 \\ & 22 \\ 2 / 13 & 25 \\ 3 / 2,3 & 37 \\ 2 / 12 & 38 \\ & 39 \\ & 40 \\ & 28 \\ 3 / 10-12 & 23 \\ 3 / 14-16 & 42 \\ & 43\end{array}$

